University of Texas Rio Grande Valley

ScholarWorks @ UTRGV

$11-2019$

\title{
M. ROBERTS (ED. and TRANS.), VENANTIUS FORTUNATUS, POEMS (Dumbarton Oaks Medieval Library 46). Cambridge, MA: Harvard University Press, 2017. Pp. xx +910. isbn9780674974920. £19.95.
}

Erica Buchberger

The University of Texas Rio Grande Valley, erica.buchberger@utrgv.edu

Follow this and additional works at: https://scholarworks.utrgv.edu/hist_fac

Part of the History Commons

\section{Recommended Citation}

Buchberger, E. (2019). M. ROBERTS (ED. and TRANS.), VENANTIUS FORTUNATUS, POEMS (Dumbarton Oaks Medieval Library 46). Cambridge, MA: Harvard University Press, 2017. Pp. xx 910. isbn9780674974920. £19.95. Journal of Roman Studies, 109, 434-435. doi:10.1017/S0075435819000054

This Book Review is brought to you for free and open access by the College of Liberal Arts at ScholarWorks @ UTRGV. It has been accepted for inclusion in History Faculty Publications and Presentations by an authorized administrator of ScholarWorks @ UTRGV. For more information, please contact justin.white@utrgv.edu, william.flores01@utrgv.edu. 
M. ROBERTS (ED. and TRANS.), VENANTIUS FORTUNATUS, POEMS (Dumbarton Oaks Medieval Library 46). Cambridge, MA: Harvard University Press, 2017. Pp. xx + 910, ISBN 9780674974920. £19.95.

Venantius Fortunatus, a sixth-century poet writing in Merovingian Gaul, has received increasing attention as more scholars have realized the inventiveness of late antique poetry. Michael Roberts is among recent contributors to our understanding of the complexity of Fortunatus' writing with his The Humblest Sparrow (2009). In his new edition and translation for the Dumbarton Oaks Medieval Library, R. provides for the first time an English translation of the entire corpus of Fortunatus' poetry (minus the Vita Sancti Martini already available elsewhere). That this much needed volume features both accessible prose and an affordable price means the beauty and skill of Fortunatus' writing can be appreciated by a far wider audience.

The volume begins with a short introduction to Fortunatus' life, writings, and unique style. Though brief, it provides the right balance between the necessary information for a general audience to appreciate the poems and the endnotes to lead scholars to recent in-depth studies and the critical apparatus of earlier editions by Leo, Reydellet, and Di Brazzano. Following this, R. proceeds to Fortunatus' preface and the twelve books of his poetry, with the Latin edition and English translation helpfully on facing pages. Books 1-3 and 5 contain poems related to religious matters and church leaders, organized, as R. points out (ix), by status of the addressee. Book 4 collects epitaphs. Books 6 and 7 are poems addressed to secular figures, including members of the Merovingian royal family. Book 8's poems are dedicated to Radegund and Agnes, founder and abbess respectively of the Convent of the Holy Cross and close friends of Fortunatus. Books 9-11 are less organized but also contain many poems to Radegund and Agnes. The final book, 'Appendix', consists of poems not found in most manuscripts of Fortunatus' corpus, collected together by Friedrich Leo in his 1881 edition and henceforth usually treated by scholars as a twelfth book. Three figure poems are reproduced at the end, followed by short but helpful notes - again well balanced between the minor variations in his edition for scholarly reference and the clear explanation of allusions and metaphors for a general audience.

R.'s stated aims for his translation are 'to produce a readable and accurate version of Fortunatus's Latin, without slavishly following the structure of the Latin when it would produce uncomfortable English' (xviii-xix). That he largely succeeds against the challenge of Fortunatus' 
wordplay and masterful alliterative invention is a testament to his own poetic skill. For example, the vivid imagery of Fortunatus' 'Nunc meliore via viruit renovata vetustas / et lapsae fabricae flos redivivus adit' becomes 'Now the old, made new, is refreshed and improved, and the flower of its fallen fabric comes back to life once more' (1.13.11-12). '... qui nos Romanos vincis in eloquio' becomes '... who in your speech outdo us Romans in ours' (6.2.100). Even simply relaying the meaning of Fortunatus' words in a readable manner can be challenging, without concern for rhythms and alliterations, yet R. produces some of the most readable translations available. In an epitaph for Leontius the Younger of Bordeaux, R. renders 'Nobilitas altum ducens ab origine nomen, / quale genus Romae forte senatus habet' as 'His nobility derives from his ancestry a lofty title, a family such as might belong to the senate at Rome' (4.10.7-8). Some might quibble at the precise parts of speech, but R.'s prose is fluid and quite faithful in meaning to the original.

One particular term stands out as out of place in a modern edition, and that is 'race'. At 4.26.15, Vilithuta is described as 'torva de gente', for R. 'from a fierce race'; at 7.7.45-6, the description of Lupus as 'Antiquos animos Romanae stirpis adeptus' is rendered 'Possessing the ancient character of the Roman race'; and at 2.8.23 Launebod, 'a man of barbarian ancestry' ('vir barbarica prole') took up duties not done by those 'descended from the Roman race' ('veniens Romana gente'). In contrast, for 'quacumque ex gente creatos', R. provides 'whatever their nationality' (3.14.5). While it could be argued that using 'nationality' rather than 'race' simply replaces one potentially anachronistic and slippery term with another, and that 'race' might even be a more accurate representation of how contemporaries would have understood gens, one must not forget that this volume and series are aimed not just at specialists but also at a more general readership. A casual reader who is dependent on the English translation is unlikely to be familiar with scholarly debates on these terms; he or she will simply see the word 'race' and all the modern baggage that comes with it. Given the recent increase in impact of that baggage, some extra caution with the term is probably warranted.

In sum, R.'s edition and translation is an impressive achievement, and a very welcome volume for specialists and general readers alike. Students will benefit from its price and readability, with R.'s notes guiding them through multiple layers of meaning. Specialists will appreciate having what will undoubtedly become the standard edition of Fortunatus' poetry in an 
accessible format on their own bookshelves. And greater accessibility means we can expect even greater scholarly exploration to come. With R.'s volume, Fortunatus returns to us here and now.

ERICA BUCHBERGER, University of Texas, Rio Grande Valley, erica.buchberger@utrgv.edu 